\title{
PHYSICAL AND CHEMICAL DEFENSES OF Cenostigma pyramidale (FABACEAE): A PIONEER SPECIES IN SUCCESSIONAL CAATINGA AREAS ${ }^{1}$
}

\author{
IZABELLA MARIA CINTRA RIBEIRO ${ }^{2}$, EMILIA CRISTINA PEREIRA DE ARRUDA ${ }^{2}$, ANTONIO FERNANDO \\ MORAIS DE OLIVEIRA ${ }^{2}$, JARCILENE SILVA DE ALMEIDA ${ }^{2 *}$
}

\begin{abstract}
Cenostigma pyramidale, a pioneer species presents in all different successional stage (early, intermediate and late) of fifteen natural regeneration areas of Caatinga after land used changed and abandonment was used to investigates the morphological and physiological attributes that are very important to xeromorphic conditions as against herbivories. Leaf samples were collected to evaluate the percentage of the herbivory and index of sclerophylly. Anatomy, histochemistry, total phenolic content, epicuticular wax load, and $n$-alkanes profile were also performed. The results showed an inverse relationship between the percentage of herbivory and the index of sclerophylly. The leaves showed typical morphological and anatomical characteristics of xeric environments plants such as uniseriate epidermis and trichomes. Furthermore, it was also noticed a decrease in the overall thickness and the tissues according to the advancement of the successional stages. The histochemical revealed the presence of lipidic substances coating the epidermal layers, phenolics compounds stored in secretory structures, and starch in the mesophyll. The concentration of phenolics compounds indicating the difference from health leaves of plants between different stages of regeneration, but no difference when they were herbivored. The amount of cuticle wax did not change significantly with the successional stage. The profile of $n$-alkanes was characterized by the predominance of nonacosane (C29) and hentriacontane (C31). The $\mathrm{C} 29$ content decreases with the advancement of the successional stage, while the C31 content increases. All those attributes have a role to protect the plants to acclimate to the various environmental conditions of Caatinga.
\end{abstract}

Keywords: Catingueira. Leaf anatomy. Secondary compounds. Leguminosae. Secondary succession.

\section{DEFESAS FÍSICAS E QUÍMICAS DE Cenostigma pyramidale (FABACEAE): UMA ESPÉCIE PIONEIRA EM ÁREAS SUCESSIONAIS DE CAATINGA}

\begin{abstract}
RESUMO - Cenostigma pyramidale, espécie pioneira, presente em todos os estádios sucessionais (inicial, intermediário e tardio) em quinze áreas de Caatinga em regeneração natural após mudança do uso da terra e abandono foi utilizada para investigar atributos morfológicos e fisiológicos, importantes para sobrevivência em condições xeromórficas assim como contra herbívoros. Foram coletadas amostras de folhas de diferentes árvores nas diferentes áreas. As folhas foram digitalizadas, calculada a porcentagem de área perdida por herbivoria, o índice de esclerofilia, descritas as principais características morfoanatômicas, realizadas análises histoquímicas, análise de compostos fenólicos totais, extraído e calculado o teor de ceras epicuticular e analisado o perfil de $n$-alcanos. Os resultados mostraram uma relação inversa entre as porcentagens de herbivoria e o índice de esclerofilia. As folhas apresentaram características morfoanatômicas típicas de plantas de ambientes xéricos, com epiderme unisseriada e tricomas. Apresentou uma diminuição na espessura total e dos tecidos de acordo com o avanço do estágio sucessional. A histoquímica revelou a presença de substâncias lipídicas revestindo as camadas epidérmicas, compostos fenólicos armazenados em estruturas secretoras e amido no mesofilo. A concentração de compostos fenólicos totais foi maior em amostras presentes nos estádios tardios e nas amostras que apresentavam herbivoria. A quantidade de cera epicuticular não alterou significativamente com o estágio sucessional. O perfil dos $n$-alcanos foi caracterizado pela predominância de nonacosano (C29) e hentriacontano (C31). O conteúdo de C29 diminuiu com o avanço do estágio sucessional, enquanto o conteúdo de C31 aumentou. Todos estes atributos desempenham uma função de proteção na aclimatação as diferentes condições ambientais da Caatinga.
\end{abstract}

Palavras-chave: Catingueira. Anatomia foliar. Compostos secundários. Leguminosae. Sucessão secundária.

\footnotetext{
${ }^{*}$ Corresponding author

${ }^{1}$ Received for publication in $05 / 21 / 2020$; accepted in $11 / 20 / 2020$.

Paper extracted from the graduate biology essay of the first author.

${ }^{2}$ Department of Botany, Universidade Federal de Pernambuco, Recife, PE, Brazil, izabella_r_@hotmail.com - ORCID: 0000-0003-34826153, emilia_arruda@yahoo.com.br - ORCID: 0000-0002-1422-2486, afmoliveira@gmail.com - ORCID: 0000-0002-0938-9345, jarcilene.almeida@ufpe.br-ORCID: 0000-0002-7118-7090.
} 


\section{INTRODUCTION}

Plants represent the main source of energy and nutrients for herbivores, but unlike their natural enemies, they are not able to move. Furthermore, they are subject to environmental adversity; for example, water availability is the main limiting factor for plants in arid and semiarid environments. However, plants can survive, grow, and reproduce in new environmental conditions through physiological and morphological adaption. Physiological, biochemical, and morphological attributes play an important role in abiotic and biotic responses to environmental conditions. These physical and/or chemical attributes could be constitutive or inductive and produce or increase production when necessary (HEIL, 2010; SANTOS et al., 2014; FALCÃO et al., 2015; 2017).

The ability of plants to alter their characteristics in response to changing environmental conditions is termed phenotypic plasticity, and it appears as morphological and/or physiological change (GRATANI, 2014; FALCÃO et al., 2015). These changes may occur in leaf size and shape, trichome count, quantitative and qualitative aspects of secondary compounds, photosynthetic capacity, growth rates, and nutrient allocation (HEIL, 2010). Arid and semiarid regions tend to present sparse vegetation under hard climatic conditions (irregular rainfall, high light incidence, low relative air humidity, high temperature, and high evapotranspiration), as well as variation in the availability of water and nutrients (FERNANDES; QUEIROZ, 2018). The situation is worse in the face of global climatic change and with the increase in changes in land use (SANTOS et al., 2014). Global climatic change is increasing the temperature and reducing precipitation in tropical regions, particularly the vegetation of Tropical Dry Forests (SANTOS et al., 2014). The increase in land-use changes results in areas of natural regeneration with different successional stages under different abiotic (air and soil humidity, temperature, soil nutrients available, and physical and chemical soil characteristics) and biotic (competition, herbivory, exotic species, loss of native species) conditions (SANTOS et al., 2011; SANTOS et al., 2014).

In general, the plants of Seasonally Dry Tropical Forests, a type of forest with marked seasonality in precipitation, have xeromorphic characteristics, with specific physiological and morphological defense mechanisms. In leaves, the epicuticular layer that covers the epidermal cells tends to be thickened, the texture is usually leathery, and the palisade parenchyma and sclerenchyma are well developed (BOEGER; WISNIEWSKI, 2003; BARROS; SOARES, 2013). Furthermore, plants in xeric habitats present an increase in the carbon/ nitrogen ratio. High light incidence increases carbon production; however, as water availability is the main limiting factor for plant growth, the increase in leaf carbon is allocated to produce C-based secondary compounds, such as phenolic compounds. Phenolic compounds, especially tannins, play a protective role against UV incidence and water loss. Tannins are responsible for the change in plant palatability, and act as a mechanical and chemical defence against herbivory and pathogens (BOEGER; WISNIEWSKI, 2003; PAULA et al., 2011; SILVA et al., 2011; AQUINO; FALCÃO; ALMEIDACORTEZ, 2017).

The Brazilian Seasonally Dry Tropical Forest, Caatinga, has a very high plant diversity and rate of endemism (BANDA-R et al., 2016), but is also a region quite degraded because of the unsustainable use of its natural resources (ARAÚJO; CASTRO; ALBUQUERQUE, 2007; SANTOS et al., 2011). In general, human occupation in the Caatinga is followed by abandonment and subsequent natural regeneration of secondary forests. Therefore, the landscape in the Caatinga is often a mosaic of remnants at different stages of succession, depending on the duration of the recovery and chronic disturbance (QUESADA et al., 2009). With the rapid destruction of tropical forests and the threat of global climate change, a greater understanding of how plant morphological and physiological patterns change is essential for the preservation of dry tropical forests (SANTOS et al., 2011; SANTOS et al., 2014). In this study, we evaluated the phenotypic plasticity in the physical and chemical defenses of individuals of Cenostigma pyramidale, a Fabaceae species that is very common in different successional areas of the Caatinga. We hypothesized that plants growing in areas with land-use change and in the initial stages of the regeneration process will allocate their resource (carbon) to growth instead of defense. Therefore, we expected that leaves subjected to herbivory will present increased chemical and physical defenses compared to healthy leaves, independent of the successional stage.

\section{MATERIALS AND METHODS}

\section{Study area}

The study was conducted in February and April during 2012 and 2013, in a chronosequence of three successional stages of a seasonally tropical dry forest (STDF), the Caatinga, in a Tamanduá farm $\left(06^{\circ} 59^{\prime} 13^{\prime \prime}\right.$ to $07^{\circ} 00^{\prime} 14^{\prime \prime} \mathrm{S}$ and $37^{\circ} 18^{\prime} 08^{\prime \prime}$ to $37^{\circ} 20^{\prime}$ $38^{\prime \prime} \mathrm{W}, 240 \mathrm{~m}$ above sea level) with 3,073 ha located in the Santa Terezinha municipality, Paraíba, Brazil.

The climate in this region is tropical semiarid (Bsh) according to the Köppen classification system. The mean temperature and annual rainfall of the city were $32.8^{\circ} \mathrm{C}$, and $600 \mathrm{~mm}$, respectively (FALCÃO et al., 2015). Precipitation was recorded monthly at a meteorological station that was installed in the study 
area. The cumulative rainfall levels up to April were $257 \mathrm{~mm} \mathrm{(2012)}$ and $338 \mathrm{~mm}$ (2013). According to Vico et al. (2015), rainfall episodes show an irregular pattern, which is usually concentrated between February and May. The soils are a pre-cambric crystalline shield, with Litholic Neosol being the predominant type, with shallow and low fertility soils (FREITAS; CIANCIARUSO; BATALHA, 2012). Further details of the soil in our study area are described in Medeiros et al. (2017).

Areas with different land-use histories and natural regeneration stages were selected for this study. The early and intermediate successional areas were submitted to clearcutting in the 1960 s for perennial cotton planting and were later replaced by Cenchrus ciliaris L. (buffelgrass) and used as pasture for cattle before being abandoned. The regeneration time after abandonment was determined through oral registration with the older local people. The areas classified as late successional were those for which there was no registry of clearcutting or major disturbances since the 1950s (SILVA; TAVARES; ALMEIDA-CORTEZ, 2012; CABRAL; SAMPAIO; ALMEIDA-CORTEZ, 2013). Additionally, in 2007, 15 permanent plots $(20 \mathrm{~m} \times 50 \mathrm{~m}$, five per regeneration stage) were surrounded with barbed wire to prevent the entry of cattle, goats, and sheep (FALCÃO et al., 2015). The land-use histories and the phytosociological survey of tree species in the study area are described in detail in Medeiros et al. (2017) and Cabral, Sampaio and Almeida-Cortez (2013), respectively.

Plant communities in the three successional stages of natural regeneration, based on Cabral, Sampaio and Almeida-Cortez (2013):

Early Stage: This is characterized by the strong presence of herbaceous species, in particular, Mesosphaerum suaveolens (L) Kuntze (Lamiaceae), which can reach almost $2 \mathrm{~m}$ in height during the rainy season (pers. obs.) and species of shrubs and tree sizes that were relatively dispersed. The authors identified six arboreal species, namely Cenostigma pyramidale (Tul.) Gagnon \& G. P. Lewis (Catingueira), Mimosa tenuiflora (Willd.) Poir (Jurema Preta), Croton blanchetianus Baill. (Marmeleiro), Bauhinia cheilantha Bong Steud (Mororó), and Caesalpinia ferrea Mart. Ex. Tul (Jucá or Pau-ferro; CABRAL; SAMPAIO; ALMEIDA-CORTEZ, 2013).

Intermediate Stage: In this stage, the arboreal vegetation is denser than in the early succession stage. Identified species present in early stages and different ones, such as Cenostigma pyramidale (Tul.) Gagnon \& G. P. Lewis, Croton blanchetianus Baill., Mimosa tenuiflora (Willd.) Poir., Piptadenia stipulacea (Benth.) Ducke (Jurema Branca), Commiphora leptophloeos (Mart.) J. B. Gillett (Imburana), and Bauhinia cheilantha Bong Steud (Mororó) (CABRAL; SAMPAIO; ALMEIDACORTEZ, 2013).
Late Stage: In areas in the late stage, the arboreal vegetation has a diversity of species in relation to the other stages, such as Cenostigma pyramidale (Tul.) Gagnon \& G. P. Lewis, Commiphora leptophloeos (Mart.) J. B. Gillett (Imburana), Anadenanthera colubrina (Vell.) Brenan (Angico-branco), Combretum leprosum Mart. (Mofumbo) and Amburana cearensis (Allemao) ACSmith (Cumaru) (CABRAL; SAMPAIO; ALMEIDA-CORTEZ, 2013).

\section{Study species}

The plant species used in this study were Cenostigma pyramidale (Tul.) Gagnon \& G. P. Lewis (syn Poincianella pyramidalis (Tul.) L.P. Queiroz; Caesalpinia pyramidalis Tul.), popularly known as "catingueira." It is a medium-sized arboreal pioneer species belonging to the family Fabaceae (Leguminosae), which is endemic to Brazil's semiarid northeastern region, having a wide distribution in the Caatinga (MAIA, 2012). It is known for its diversity of potential uses, such as for wood and charcoal, medicinal purposes, replanting of degraded areas, and agroforestry systems (MAIA, 2012). Its leaves are compound, with 5-11 leaflets, and the adult plants flower for four months during the rainy season. According to Cabral, Sampaio and Almeida-Cortez (2013), this species is present in all studied plots in the three successional stages.

We selected three medium-sized trees (height 2-4 m) in each plot (five plots $\times$ three regeneration stages) and we harvested 50 mature leaves (leaf blade $11-51 \times 7.5-31 \mathrm{~mm})$. The leaves were conditioned in paper bags and brought to the Multitrophic Interactions Laboratory (LIM-UFPE).

\section{Herbivory percentage}

Ten leaves were randomly chosen from the pool of 50 mature leaves from each individual (10 leaves $\times$ three trees $\times$ five plots $\times$ three successional stages) and used to calculate the percentage of herbivory and sclerophylly index. All leaves were scanned with the aid of ImageJR software ver. 1.45a (NIH, Bethesda, MD), and the total leaf area and the area removed by herbivory or unknown factors were calculated (RASBAND, 1997). The percentage of herbivory in the different successional stages was calculated using the following formula:

$$
\% \text { of Herbivory }=\frac{\text { Lost area }\left(\mathrm{cm}^{2}\right)}{\text { Total area }\left(\mathrm{cm}^{2}\right)} \times 100
$$

The results were analyzed using statistical tests (ANOVA and Tukey's test at the 5\% level of significance) using GraphPad Prism 5.0 software (GraphPad Software, San Diego, CA, USA). 


\section{Sclerophylly index}

Sclerophylly means "hard-leaved," and is typically used to distinguish xeromorphic plants with leathery leaves from those exhibiting succulence or leaflessness. Several different sclerophylly indices are described in the literature. We selected the specific leaf area (SLA) as the sclerophylly index in this study. After measuring the leaf area, the leaves were dried at $100{ }^{\circ} \mathrm{C}$ to a constant weight, and the dry mass (DM, g) was measured using a precision analytical balance (BOEGER; WISNIEWSKI, 2003). Finally, SLA was calculated using the following formula:

$$
\text { Specific Leaf Area }=\frac{\text { Leaf Area }\left(\mathrm{cm}^{2}\right)}{\text { Leaf Mass }(\mathrm{g})}
$$

\section{Leaf epicuticular wax content and $n$-alkane profile}

Twenty leaves from the pool of the 50 mature leaves from each individual (10 leaves suffering from herbivory and 10 leaves that were not $\times$ three trees $\times$ five plots $\times$ three successional stages) were scanned and their average leaf area was determined with the aid of ImageJR software ver. 1.45a (NIH, Bethesda, MD, USA).

Samples of fresh whole leaves $(\mathrm{n}=20)$ were briefly washed three times with $\mathrm{CH}_{2} \mathrm{Cl}_{2}(20 \mathrm{~mL})$ with constant agitation. The solvent was then evaporated to dryness to obtain a crude extract. The extract was concentrated in a rotary evaporator and later in gaseous nitrogen, remaining in a desiccator until analysis. The epicuticular wax content was calculated as the ratio between the wax mass $(\mu \mathrm{g})$ and total leaf area $\left(\mathrm{cm}^{2}\right)$, considering the sum of the adaxial and abaxial areas according to formula below:

$$
\text { Average wax content }=\frac{\text { Wax obtained }(\mu \mathrm{g})}{\text { Total leaf area }\left(\mathrm{cm}^{2}\right)}
$$

The crude wax was fractionated, by thin-layer chromatography (TLC) and the $n$-alkanes present in the epicuticular wax were analyzed by (GC/MS) gas chromatography coupled to mass spectrometry according to Oliveira and Salatino (2000).

\section{Histology and histochemistry of leaflets}

Ten leaves were randomly chosen from the pool of 50 mature leaves from each individual (10 leaves $\times$ three trees $\times$ five plots $\times$ three successional stages), fixed in FAA50 (formaldehyde, acetic acid, and $50 \%$ ethanol), and serially dehydrated with ethanol-butanol $50-100 \%$ pure butanol. They were then embedded in paraffin, blocked, and cross- sectioned on a rotating microtome (Hyrax M 55 model; Zeiss, Jena, Germany), where the thickness of the cut varied from 10 to $12 \mu \mathrm{m}$. The sections obtained were stained with Alcian blue and safranin (KRAUS; ARDUIN, 1997), and then mounted on permanent slides in Canada balsam. From these slides, the total thickness of (i) the leaflets, (ii) the adaxial and abaxial epidermis, (iii) the palisade and lacunous parenchyma, and (iv) the cuticle were measured. Histochemical tests were also performed, where the leaflet samples were subjected to the following reagents: Lugol's iodine for starch detection, ferric chloride for detection of phenolic compounds, and Sudan III for detection of lipid substances (SANT'ANNA-SANTOS et al., 2006).

\section{Content of total phenolic compounds}

Phenolic compounds are well-known phytochemicals found in all plants. Ten leaves were randomly chosen from the pool of 50 mature leaves from each individual (10 leaves $\times$ three trees $\times$ five plots $\times$ three successional stages), and dried in the shade at room temperature. These leaves were then divided into two groups: leaflets that suffered herbivory and those that did not, and then chopped and ground. The ground powders were mixed with absolute ethanol using a powder/solvent ratio of 1:8 $(\mathrm{w} / \mathrm{v})$ and stirred continuously at room temperature four times for $4 \mathrm{~h}$.

The ethanolic extracts obtained were used to determine the content of total phenolic compounds using the modified Folin-Ciocalteu method (BONOLI et al., 2004). The ethanolic extract (100 $\mathrm{mg}$ ) was dissolved in methanol and quantitatively transferred to a $100 \mathrm{~mL}$ volumetric flask, and the final volume was completed with methanol. A 7.5 $\mathrm{mL}$ aliquot of this solution was transferred to a 50 $\mathrm{mL}$ volumetric flask, which was then metered again with methanol. A $100 \mu \mathrm{L}$ aliquot of this latter solution was stirred with $500 \mu \mathrm{L}$ of Folin Ciocalteu reagent and $6 \mathrm{~mL}$ of distilled water for $1 \mathrm{~min}$ and then $2 \mathrm{~mL}$ of $15 \% \mathrm{Na}_{2} \mathrm{CO}_{3}$ was added to the mixture and stirred for $30 \mathrm{~s}$. Finally, the solution was brought to $10 \mathrm{~mL}$ with distilled water. The reaction was left to proceed for $30 \mathrm{~min}$. The absorbance was measured in triplicate at $750 \mathrm{~nm}$. The blank consisted of all reagents, excluding the sample extract. A standard curve was generated using gallic acid such that total phenolic concentration was expressed as mg of gallic acid equivalents per gram of dried fraction.

\section{Statistical analysis}

The percentage of herbivory, the index of sclerophylly, biometrics leaflet histology sections, the content of epicuticular wax, and total phenolic compounds were expressed as means \pm S.E.M. A one -way ANOVA followed by Tukey's test was used to determine significance when comparing the 
successional stages (early, intermediate, and late). $\mathrm{P}$ values less than $0.05,0.01$, and 0.001 were considered significant $(* \mathrm{p}<0.05, * * \mathrm{p}<0.01, * * * \mathrm{p}<$ 0.001). Graph Pad Prism 5 was used for statistical calculations (GraphPad Software).

\section{RESULTS AND DISCUSSION}

\section{Herbivory percentage}

The percentage of herbivory was similar for all samples, with no significant difference between the averages observed for each succession stage studied (Figure 1). Ribeiro et al. (2013) investigated the relationship between herbivory and fluctuating asymmetry (FA) in Poincianella pyramidalis
(Cenostigma pyramidale) in abandoned pasture and mature dry forest and concluded that the type of habitat influenced FA, as well as the percentage of leaf loss. The plants subjected to stressful environments tended to be more asymmetric with reduced defenses and were more vulnerable to herbivory. FA could alter the characteristics of plants, thereby changing their chances of survival. Ribeiro et al. (2013) presented similar herbivory data in the studied areas. In this study, individuals of Cenostigma pyramidale showed a positive relationship between FA and herbivory. This indicates that herbivores select plants that are more asymmetric, regardless of the type of habitat involved, which might be attributable to the mechanisms posited in the plant stress hypothesis.

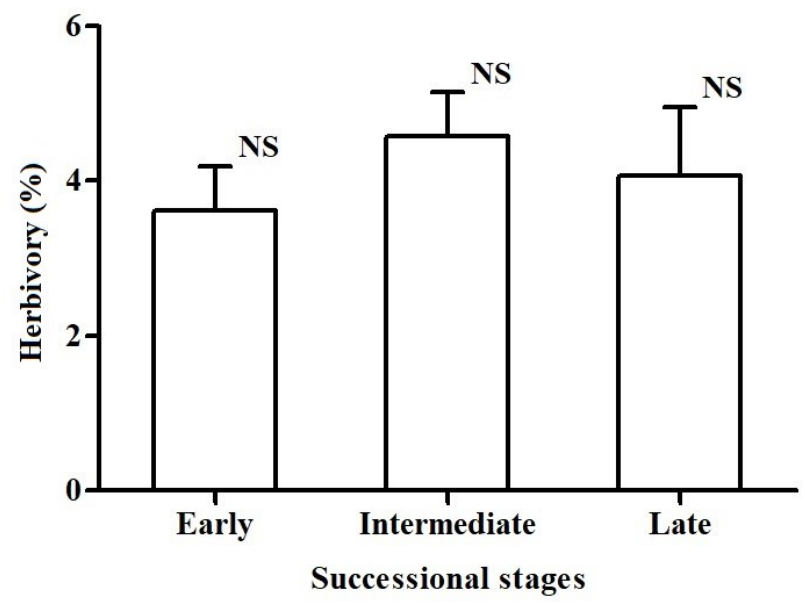

Figure 1. Percentage of herbivore leaves of Cenostigma pyramidale at three successional stages of natural regeneration in tropical dry areas (NE Brazil, $\mathrm{n}=450)($ mean $\pm \mathrm{SD})$. NS means not significant $(\mathrm{P}<0.05)$, using ANOVA One way followed by Tukey $5 \%$.

\section{Sclerophylly index}

There was a significant difference in the SLA between the early and intermediate stages (Figure 2). Using the SLA as a sclerophylly index, the leaves of individuals that occurred in the early stage were more sclerophyllous than those that occurred in the intermediate stage. Boeger and Wisniewski (2003) found similar results using the same index, where the values obtained for the early stage (58.7) were lower than those obtained for the intermediate (71.7) and advanced (87.7) stages. The results presented also corroborate those of the percentage of herbivory because the SLA is directly related to the resistance to herbivore attack (AQUINO; FALCÃO; ALMEIDA-CORTEZ, 2017).

Falcão et al. (2015) investigated the functional traits that allowed plants to maintain their performance throughout the succession process. The study was conducted in areas with different periods of regeneration in a TDF using the same target species. The authors found that rainfall differences between years influenced the SLA more than did the regeneration stages. Otherwise, they observed that concerning the construction costs per mass, the leaf construction cost per unit area did not differ between successional stages. The SLA includes the main component of leaf water content; thus, leaf tissue density decreases as leaf water content increases and is influenced by precipitation. The area of the leaf could be influenced by air and soil humidity and temperature. The seasonally dry tropical forest has a very irregular rainfall between years, and according to Vico et al. (2015), it is possible to capture the effects of the occurrence of rainfall on water availability and $\mathrm{C}$ dynamics. Additionally, the authors raised the hypothesis that among droughtdeciduous species, the inter-annual variability in rainfall is likely to support the coexistence of multiple leaf flushing strategies, e.g., flushing in response to small rainfall events, in which the leaves could be smaller but increase in SLA. Therefore, 
during the process of natural regeneration, pioneer species, such as Cenostigma pyramidale, have high rates of growth and survival, and these characteristics may be associated with low leaf construction costs; i.e., these plants require less energy and use it more efficiently for the production of biomass than those of the late-successional stages (FALCÃO et al., 2015). Nevertheless, other ecological and evolutionary factors may influence the sclerophylly index observed in SDTFs, such as herbivore-leaf interactions, nutrient availability, and evolutionary legacies (VICO et al., 2015). However, the sclerophylly index is important to study the palatability to herbivores, in particular the insects. The leaf structure, for example, toughness, may influence herbivory.

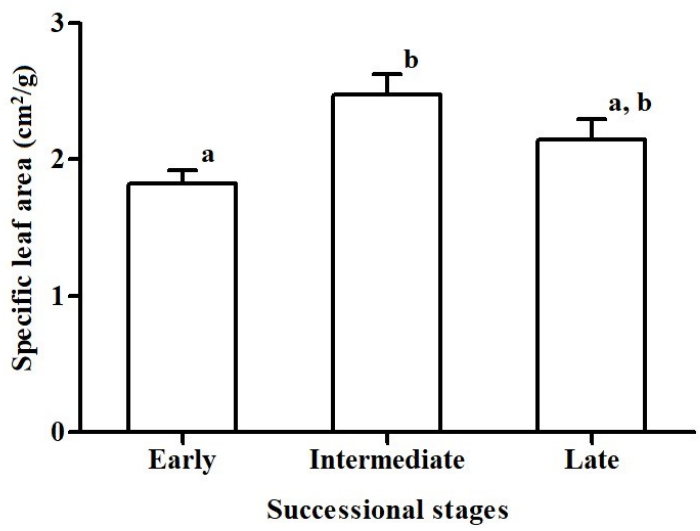

Figure 2. Specific leaf area $\left(\mathrm{cm}^{2} / \mathrm{g}\right)$ of Cenostigma pyramidale at three successional stages of natural regeneration of the tropical dry areas $(\mathrm{NE}$ Brazil, $\mathrm{n}=450)($ mean $\pm \mathrm{SD})$. Equal letters mean that the average values do not present a significant difference among different sites $(\mathrm{P}<0.05)$, using ANOVA One way followed by Tukey $5 \%$.

Leaf epicuticular wax content and $n$-alkane profile

Leaf epicuticular wax, as an essential barrier, is a very important component of terrestrial plants. Characteristic epicuticular wax compositions, especially $n$-alkanes, are found among different kinds of plants. Regarding the average epicuticular wax content per surface unit, there was no significant difference between successional stages (Figure 3). According to previous studies, the expression of wax may be related to various biotic (VARANDA; SANTOS, 1996) and abiotic factors (OLIVEIRA; SALATINO, 2000). In the latter case, the wax content is mainly related to its ability to reduce water loss. For Caatinga species, the maintenance of a hydric balance is a serious problem; thus, higher restriction of water loss is expected for plants in the Caatinga. Our findings showed that the maintenance of a balanced hydrophobic layer in the three successional stages can ensure better survival for the individuals of Cenostigma pyramidale. This characteristic can be decisive for this species that is considered one of the most frequent in the Caatinga (CABRAL; SAMPAIO; ALMEIDA-CORTEZ, 2013). The similarity between wax content in individuals at different successional stages corroborates the herbivory data obtained in the present study. According to Eigenbrode (1996), epicuticular waxes, in quantity and composition, are effective barriers against herbivorous insects.

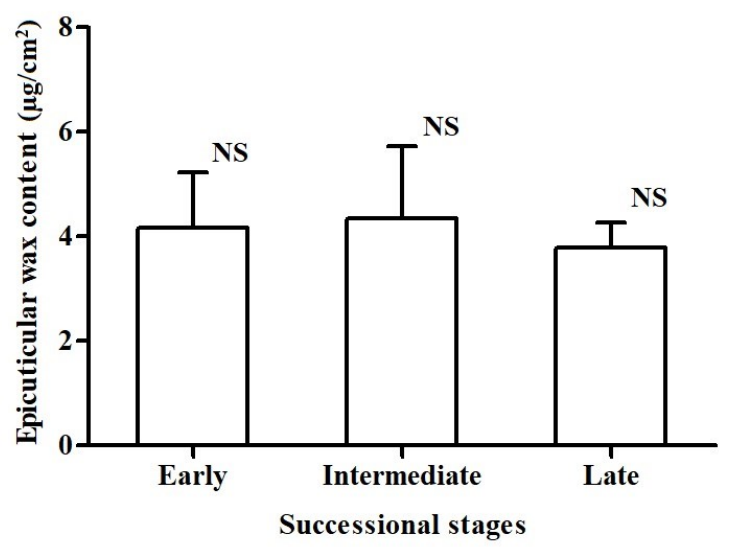

Figure 3. Epicuticular wax content of Cenostigma pyramidale at three natural regeneration stages of the tropical dry areas $(\mathrm{NE}$ Brazil, $\mathrm{n}=450)($ mean $\pm \mathrm{SD})$. NS means not significant $(\mathrm{P}<0.05)$, using ANOVA One Way followed by Tukey $5 \%$. 
Analysis of the $n$-alkane profile revealed that the leaf epicuticular wax of Cenostigma pyramidale has chains ranging from 25 to 33 carbon atoms. These results agree with those found in plants studied in dry tropical forests (VARANDA; SANTOS, 1996; OLIVEIRA; MEIRELLES; SALATINO, 2003). Oliveira, Meirelles and Salatino (2003) observed that the $n$-alkane fractions formed mainly by homologs with 27-33 carbon atoms, which were the most effective wax components to reduce water loss. This attribute is very important to species living in seasonally stressful habitats. According to some authors, long-chain $n$-alkanes in the epicuticular wax of Caatinga species are important factors related to increased drought tolerance in native species (OLIVEIRA; MEIRELLES; SALATINO, 2003; FIGUEIREDO et al., 2012; PEREIRA et al., 2019).

Our findings showed that long-chain $n$ alkanes nonacosane (C29) and hentriacontane (C31) were the main constituents in the individuals from different successional stages, with $\mathrm{C} 29$ having the highest concentration in the early stage and C31 the highest concentration in the late stage. For Cenostigma pyramidale, the occurrence of longchain $n$-alkanes in epicuticular wax can ensure a better adaptive response to water stress. The earlystage areas are more open, increasing the evapotranspiration, air and soil temperature, and reducing the air humidity. Otherwise, late stages present more species and more individuals per species, increasing the soil water competition.

\section{Histology and histochemistry of leaflets}

The lining system of Cenostigma pyramidale leaflets consists of a uniseriate epidermis, unicellular tectorial trichomes, stomata occurring on the adaxial and abaxial surfaces, and glandular trichomes on the abaxial surface. The mesophyll is a dorsiventral type consisting of 1-2 layers of palisade parenchyma and 3-4 layers of lacunous parenchyma (Figures 4A and B). Vascular bundles are collateral and associated with pericyclic fibers (Figure 4C). The secretory structures are located in the lacunous parenchyma (Figure 4D), prismatic crystals (Figure 4E), and druses (Figure 4F) near the fibers of the pericycle. According to Fahn and Cutler (1992), smaller leaf area and a greater number of strata of the palisade parenchyma should be able to compensate for the reduction in leaf area; thus, contributing to the increase in the total leaf thickness, as a response to light intensity. In general, the structural characteristics observed are typical in species that occur in xeric environments and act by minimizing the damage caused by direct solar radiation on the leaf and reflect the excessive incidence of ultraviolet rays. One of these main characteristics is trichomes, which are physical barriers to light absorption, maintain moisture and temperature on the leaf surface, and protect against herbivores, a role played by secretory or glandular trichomes (FAHN; CUTLER, 1992).
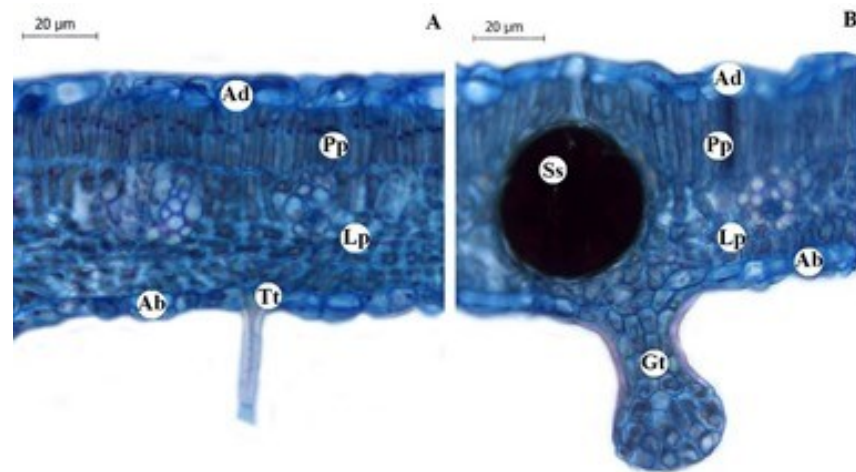

B $20 \mu \mathrm{m}$

C
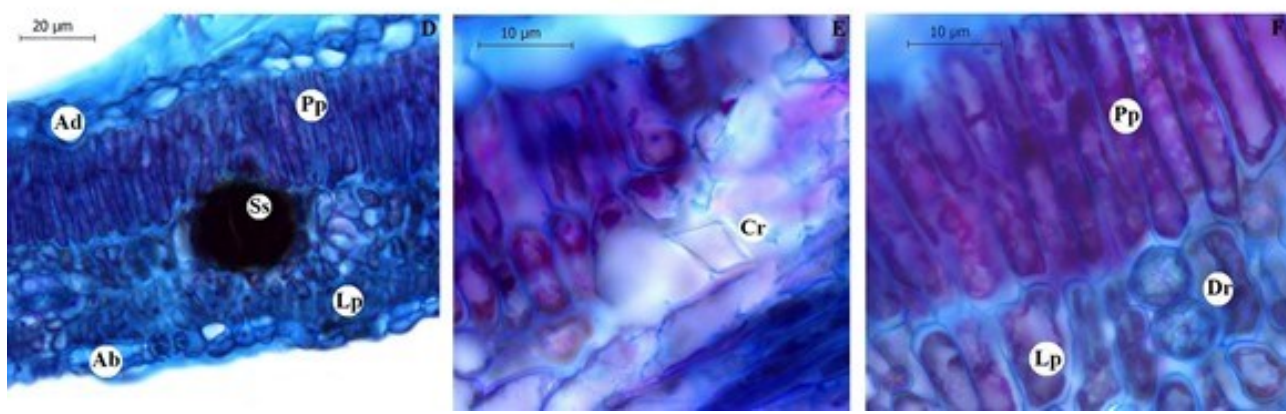

Figure 4. Transverse sections of Cenostigma pyramidale leaflets showing the morphhoantomic characteristics. A: General aspect of the dorsiventral mesophyll, with adaxial $(\mathrm{Ad})$ and abaxial $(\mathrm{Ab})$ epidermis, 1-2 layers of palisade parenchyma $(\mathrm{Pp})$ and 3-4 lacunous parenchyma ( $\mathrm{Lp}$ ) and tectorial trichomes $(\mathrm{Tt})$. B: glandular trichome $(\mathrm{Gt})$. C: General aspect of the main collateral rib, with bundles of xylem $(\mathrm{Xy})$ and phloem $(\mathrm{Ph})$ associated with pericyclic fibers $(\mathrm{Fb})$. $\mathrm{D}$ : secretory structure (Ss). E: prismatic crystal (Cr). F: drusen (Dr).

Rev. Caatinga, Mossoró, v. 34, n. 2, p. 398 - 409, abr. - jun., 2021 
Biometric data for the total and tissue thicknesses of Cenostigma pyramidale leaflets, despite not showing any significant difference, suggest a tendency to decrease in total thickness and thickness of the cuticle, epidermis, and lacunous parenchyma during progression in the succession process. The palisade parenchyma was the only tissue that showed a significant decrease in thickness when comparing the values for the three successional stages (Table 1). Some of these characteristics, such as a greater total thickness and palisade parenchyma, have been identified as strategies to increase cuticular resistance against water loss in xerophytes (FAHN; CUTLER, 1992). Biometric data showed a high standard deviation in the leaves of trees growing in some plots, which could be related to the phenotypic plasticity of this species. The literature suggests that phenotypic plasticity can evolve when there is sufficient genetic variation caused by genetic correlations with other traits that are under selection (GRATANI, 2014 and their references).

Table 1. Biometric data $(\mu \mathrm{m})$ of the tissues that make up the Cenostigma pyramidale leaflet at three successional stages of natural regeneration in tropical dry areas $(\mathrm{NE}$ Brazil, $\mathrm{n}=20)($ mean $\pm \mathrm{SD})$. Different letters in the same column $(=$ same variable) means that the average values present a significant difference among different sites $(\mathrm{P}<0.05)$ means that the average values are statistically different $(\mathrm{P}<0.05)$, using ANOVA followed by Tukey $5 \%$.

\begin{tabular}{|c|c|c|c|c|c|c|c|}
\hline Stage & Plots & Total thickness & Adaxial face cuticle & Adaxial face epidermis & Abaxial face epidermis & Palisade parenchyma & Lacunous parenchyma \\
\hline & E1 & $61.25( \pm 8.3)$ & $1( \pm 0)$ & $8( \pm 1.63)$ & $5.5( \pm 1.73)$ & $27.25( \pm 4.57)$ & $19.5( \pm 7.85)$ \\
\hline & E2 & $51( \pm 4.24)$ & $1.25( \pm 0.50)$ & $7.25( \pm 2.75)$ & $4.75( \pm 1.26)$ & $20.75( \pm 4.92)$ & $17( \pm 2.94)$ \\
\hline \multirow[t]{3}{*}{ Early (E) } & E3 & $54.25( \pm 7.89)$ & $1.25( \pm 0.50)$ & $6( \pm 1.63)$ & $5.25( \pm 1.89)$ & $22.25( \pm 9)$ & $19( \pm 4.24)$ \\
\hline & E4 & $58.5( \pm 10.91)$ & $1( \pm 0)$ & $7.75( \pm 1.71)$ & $5.25( \pm 1.71)$ & $23.5( \pm 5.97)$ & $21.75( \pm 3.95)$ \\
\hline & E5 & $51( \pm 10.1)$ & $1.25( \pm 0.5)$ & $5.25( \pm 0.96)$ & $4.5( \pm 0.58)$ & $17.75( \pm 4.99)$ & $16.75( \pm 4.27)$ \\
\hline \multirow[t]{3}{*}{ Average } & & $55.2( \pm 4.57)^{\mathrm{a}}$ & $1.25( \pm 0.14)^{\mathrm{a}}$ & $7.25( \pm 1.18)^{\mathrm{a}}$ & $5.19( \pm 0.41)^{\mathrm{a}}$ & $23.44( \pm 3.5)^{\mathrm{a}}$ & $18.8( \pm 2.04)^{\mathrm{a}}$ \\
\hline & I1 & $56( \pm 7.79)$ & $1.25( \pm 0.5)$ & $6.75( \pm 1.71)$ & $5.5( \pm 0.58)$ & $18.5( \pm 5.45)$ & $25.5( \pm 3.79)$ \\
\hline & I 2 & $49.25( \pm 9.43)$ & $1.5( \pm 1)$ & $7( \pm 1.41)$ & $5( \pm 0)$ & $17( \pm 8.91)$ & $20.25( \pm 3.1)$ \\
\hline \multirow[t]{3}{*}{ Intermediate (I) } & $\mathrm{I} 3$ & $60( \pm 7.07)$ & $1.5( \pm 1)$ & $7( \pm 0.82)$ & $5( \pm 0.82)$ & $20.75( \pm 4.35)$ & $24.25( \pm 2.99)$ \\
\hline & I4 & $46.75( \pm 5.38)$ & $1( \pm 0)$ & $5.75( \pm 0.96)$ & $4( \pm 0.82)$ & $16.75( \pm 2.36)$ & $20( \pm 6.27)$ \\
\hline & I5 & $45.5( \pm 9.71)$ & $1( \pm 0)$ & $5( \pm 2.45)$ & $4( \pm 1.41)$ & $17.25( \pm 4.43)$ & $19.25( \pm 4.57)$ \\
\hline \multirow[t]{3}{*}{ Average } & & $51.5( \pm 6.25)^{\mathrm{a}}$ & $1.25( \pm 0.25)^{\mathrm{a}}$ & $6.3( \pm 0.89)^{\mathrm{a}}$ & $4.7( \pm 0.67)^{\mathrm{a}}$ & $18.05( \pm 1.65)^{\mathrm{b}}$ & $21.85( \pm 2.82)^{\mathrm{a}}$ \\
\hline & L1 & $56.5( \pm 2.89)$ & $1( \pm 0)$ & $5.25( \pm 0.5)$ & $5( \pm 0.82)$ & $19.25( \pm 5.32)$ & $23.5( \pm 7)$ \\
\hline & L2 & $54.5( \pm 13.08)$ & $1.25( \pm 0.5)$ & $6.5( \pm 1)$ & $5( \pm 0)$ & $16.75( \pm 3.59)$ & $24( \pm 9.38)$ \\
\hline \multirow[t]{3}{*}{ Late (L) } & L3 & $49( \pm 7.26)$ & $1.25( \pm 0.5)$ & $6.25( \pm 0.96)$ & $4.75( \pm 0.96)$ & $16.75( \pm 6.99)$ & $18.25( \pm 4.27)$ \\
\hline & L4 & $46.5( \pm 6.24)$ & $1( \pm 0)$ & $6.25( \pm 1.5)$ & $4.25( \pm 0.5)$ & $16( \pm 2.71)$ & $18.5( \pm 2.38)$ \\
\hline & L5 & $51.5( \pm 5.07)$ & $1( \pm 0)$ & $7.25( \pm 1.5)$ & $4.75( \pm 1.5)$ & $15.25( \pm 2.22)$ & $19.75( \pm 2.06)$ \\
\hline Average & & $51.6( \pm 4.04)^{\mathrm{a}}$ & $1.1( \pm 0.14)^{\mathrm{a}}$ & $6.3( \pm 0.72)^{\mathrm{a}}$ & $4.75( \pm 0.31)^{\mathrm{a}}$ & $16.80( \pm 1.5)^{\mathrm{b}}$ & $20.8( \pm 2.76)^{\mathrm{a}}$ \\
\hline
\end{tabular}

The samples of healthy and herbivorous leaflets in the different successional stages did not present significant differences in the histochemical tests. The results were as follows: (i) the cuticle, secretory structures, protective trichomes, pericyclic fibers, and healing tissues reacted to Sudan III used for lipid detection (Figures 5A and B); (ii) the secretory structures and glandular trichomes reacted to ferric chloride, used to detect phenolic compounds, probably because of the presence of tannins in the content of these structures (Figure 5C); and (iii) mesophyll, stomata guard cells, and glandular trichomes reacted to the Lugol's iodine used for starch detection (Figure 5D).

The epidermal cells were cuticle-coated with tector trichomes. The chemical composition of the cuticle was varied, with cutin and wax being its main components. Cutin is an insoluble biopolyester with a high degree of cross-linking between its long-chain hydroxylated fatty acids, whereas wax is embedded in this polymer or deposited on the outside of the cuticle (epicuticular wax) (LI-BEISSON et al., 2016). In herbivorous leaflets, healing tissues that probably contained suberin were identified. Injury often stimulates mitotic activity accompanied by suberization. Suberin is a hydrophobic substance and it is this characteristic gives it protective properties (LI-BEISSON et al., 2016). The secretory structures present in Cenostigma pyramidale leaflets are used for the storage of phenolic compounds. These metabolites are produced in the endoplasmic reticulum, cytoplasm, and vacuoles, and accumulate mainly in this organelle, but also in the plasma membrane and/or cell wall, which may undergo exocytosis. They can be found in all plant organs, including these secretory structures (BARROS; SOARES, 2013). 


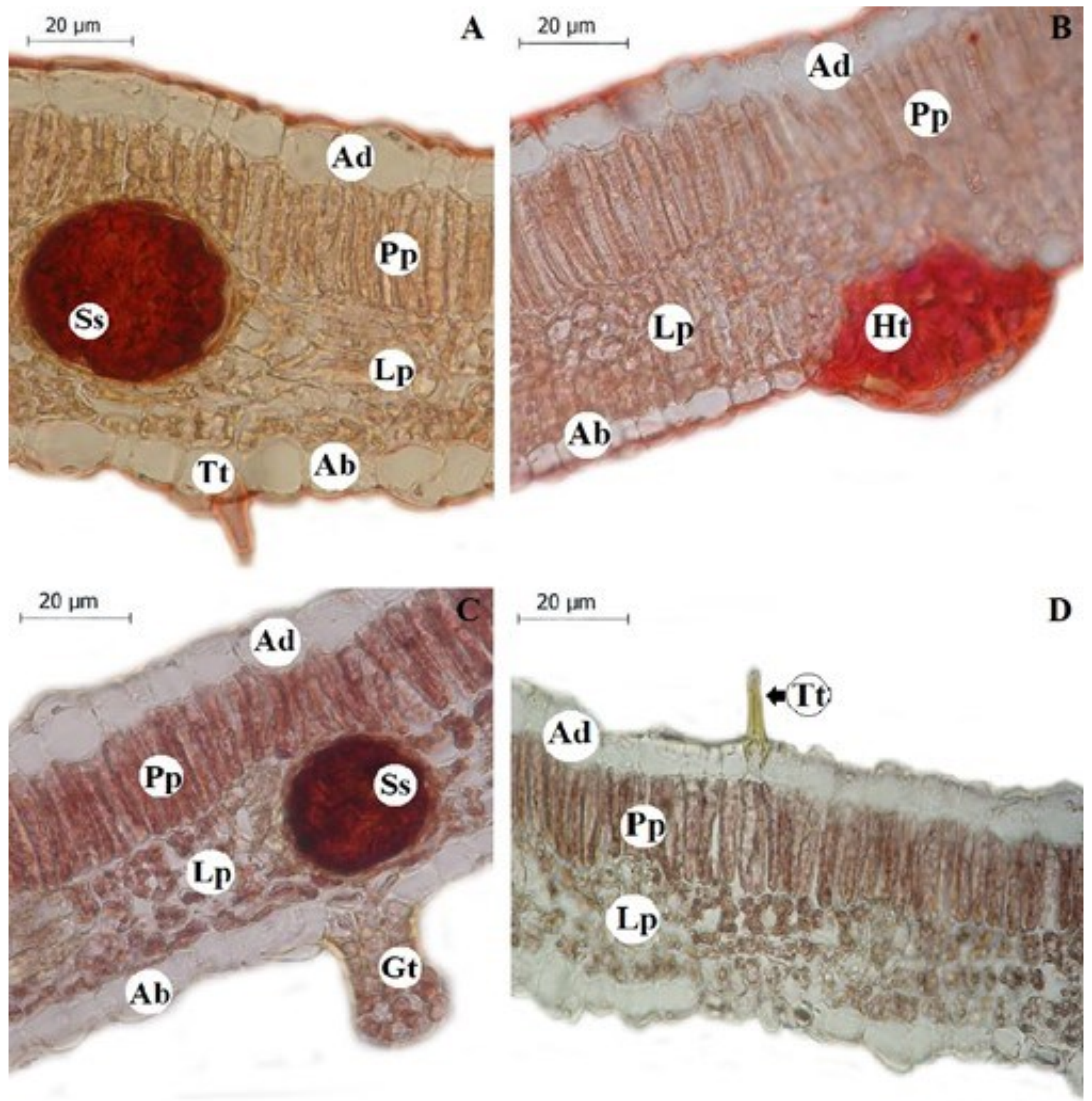

Figure 5. Leaflets of Cenostigma pyramidale (Fabaceae) cross sections: structure and histochemisty. A: The lipid droplets were marked with Sudam III in cuticle covering the adaxial epidermis (Ad), abaxial epidermis $(\mathrm{Ab})$ and the tector trichomes $(\mathrm{Tt})$, and the secretory structure $(\mathrm{Ss})$. B: the orange color in the healing tissue $(\mathrm{Ht})$ by the presence of Sudam III marked suberin. C: Orange color within the secretory structure (Ss), indicating the presence of ferric chloride marked phenolic compounds. D: brown staining of starches in the palisade parenchyma (Pp) and lacunous parenchyma (Lp) marked by Lugol's iodine.

\section{Content of total phenolic compounds}

The contents of total phenolic compounds in healthy leaflets ranged from $40.29 \mathrm{mg} / \mathrm{g}$ in the early stage to $185.71 \mathrm{mg} / \mathrm{g}$ in the late stage, and there was a significant difference between the early and late stages, but there was no difference between the early and intermediate stages, or intermediate and late stages (Figure 6A). Although the leaves present in the early stage should be exposed to greater light intensity, Cenostigma pyramidale, a pioneer species, could allocate the carbon to growth instead of carbon -based compounds, such as phenolics. Therefore, in the late stage, they should invest more in defenses (phenolic compounds) once the competition for soil nutrients and carbon increases with the number of different species and the number of plants increase per area (COLEY; BARONE, 1996). 

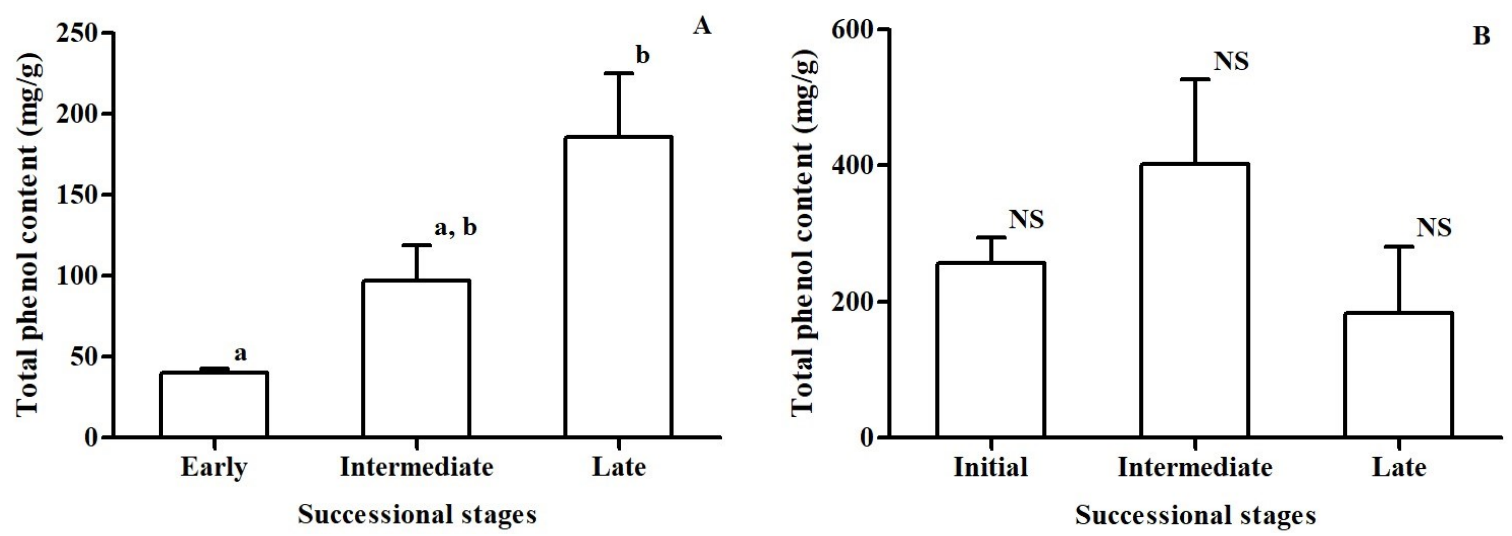

Figure 6. Content of total phenolic compounds in healthy (A) and herbivore (B) leaflets of Cenostigma pyramidale at three successional stages of natural regeneration in tropical dry areas $(\mathrm{NE}$ Brazil, $\mathrm{n}=45)$ (mean $\pm \mathrm{SD})$. Equal letters mean that the average values do not present a significant difference among different sites $(\mathrm{P}<0.05)$ and NS means not significant $(\mathrm{P}<$ $0.05)$, using ANOVA followed by Tukey 5\%.

The levels of total phenolic compounds in herbivorous leaflets ranged from $182.26 \mathrm{mg} / \mathrm{g}$ at the late stage to $402.86 \mathrm{mg} / \mathrm{g}$ at the intermediate stage. Compared with the averages of phenolic compounds in healthy leaflets, we noticed an increase in the production of this secondary compound in the initial and intermediate stages (Figure 6B). Phenolic compounds are synthesized in plants partly as a response to ecological and physiological pressures, such as pathogens and insect attacks, UV radiation, and wounding. Plant phenolics are comprised of simple phenols, coumarins, lignins, lignans, condensed and hydrolyzable tannins, phenolic acids, and flavonoids. One major class of phenolic compounds is cell wall phenolics (lignins and hydroxycinnamic acids), which plays a critical role in the cell wall during plant growth by protecting against stresses, such as infection, wounding, and UV radiation. Hence, these abiotic and biotic factors influence the redistribution of these substances in plants, as well as changes in plant phenolic levels during plant development (RAMAKRISHNA; RAVISHANKAR, 2011; AQUINO; FALCÃO; ALMEIDA-CORTEZ, 2017).

\section{CONCLUSIONS}

The pioneer species Cenostigma pyramidale was present in all successional stages of natural regeneration after land-use change. Abandonment was used to investigate the key morphological and physiological attributes that protect against herbivory in xeromorphic conditions. The data showed that SLA and total and tissue thickness of the leaflets from individuals present at the early successional stage are more sclerophyllous than those from the individuals at the most advanced successional stages. Additionally, epicuticular wax composition (e.g., $n$ alkanes profile) and content of phenolic compounds indicated a difference in the healthy leaves of plants between different stages of regeneration, but no difference when they had suffered herbivory. All these attributes played a role in protecting plants and allowing them to acclimate to the various environmental conditions of the Caatinga; in particular, the protection of leaves against abiotic (water loose, UV radiation, high temperature) and biotic adversity (herbivory and pathogens).

\section{ACKNOWLEDGEMENTS}

We gratefully acknowledge the staff of the Instituto Fazenda Tamanduá for allowing us to stay and work on the Tamanduá Farm and for their logistical support. This study was supported by Conselho Nacional de Desenvolvimento Científico e Tecnológico (CNPq - 563304/2010-3) and Fundação de Amparo à Pesquisa do Estado de Minas Gerais (FAPEMIG - Proc. CRA APQ-00001-11). Finally, J.S. Almeida thanks to Conselho Nacional de Desenvolvimento Científico e Tecnológico (CNPq PQ 309965/2016-0) and Fundação de Amparo à Ciência e Tecnologia de Pernambuco (FACEPE) for the financial support. We would like to thank Editage (www.editage.com) for English language editing

\section{REFERENCES}

AQUINO, R. E.; FALCÃO, H. M.; ALMEIDACORTEZ, J. S. Variação nas concentrações de compostos fenólicos e nas taxas de herbivoria em Aspidosperma pyrifolium Mart. em áreas antropizadas de Caatinga. Journal of Environmental Analysis and Progress, 2: 61-71, 2017.

ARAÚJO, E.; CASTRO, C.; ALBUQUERQUE, U. Dynamics of Brazilian Caatinga - A review 
concerning the plants, environment and people. Functional Ecosystems and Communities, 1: 1529, 2007.

BANDA-R, K. et al. Plant diversity patterns in neotropical dry forests and their conservation implications. Science, 353: 1383-1387, 2016.

BARROS, I. O.; SOARES, A. A. Adaptações anatômicas em folhas de marmeleiro e velame da Caatinga brasileira. Revista Ciência Agronômica, 44: 192-198, 2013.

BOEGER, M. R. T.; WISNIEWSKI, C. Comparação da morfologia foliar de espécies arbóreas de três estádios sucessionais distintos de floresta ombrófila densa (Floresta Atlântica) no Sul do Brasil. Revista Brasileira de Botânica, 26: 61-72, 2003.

BONOLI, M. et al. Antioxidant phenols in barley (Hordeum vulgare L.) flour: comparative spectrophotometric study among extraction methods of free and bound phenolic compounds. Journal of Agricultural and Food Chemistry, 52: 5195-5200, 2004.

CABRAL, G. A. L.; SAMPAIO, E. V. S. B.; ALMEIDA-CORTEZ, J. S. Spatial Structure and Aboveground Biomass in Different Caatinga Succession Stages, in Santa Terezinha, Paraiba. Revista Brasileira de Geografia Física, 6: 566-574, 2013.

COLEY, P. D.; BARONE, J. A. Herbivory and plant defenses in tropical forests. Annual Review of Ecology and Systematics, 27: 305-335, 1996.

EIGENBRODE, S. D. Plant surface waxes and insect behaviour. In: KERSTIENS, G. Plant Cuticles - An Integrated Functional Approach. Ed. BIOS Scientific Publishers: Oxford, UK, p. 201-222, 1996.

FALCÃO, H. M. et al. Phenotypic plasticity and ecophysiological strategies in a tropical dry forest chronosequence: A study case with Poincianella pyramidalis. Forest Ecology and Management, 340: 62-69, 2015.

FALCÃO, H. M. et al. Leaf construction cost is related to water availability in three species of different growth forms in a Brazilian tropical dry forest. Theoretical and Experimental Plant Physiology, 29: 95-108, 2017.

FERNANDES, M. F.; QUEIROZ, L. P. Vegetação e flora da Caatinga. Ciência e Cultura, 70: 51-56, 2018.

FIGUEIREDO, K. V. et al. Epicuticular-wax removal influences gas exchange and water relations in the leaves of an exotic and native species from a Brazilian semiarid region under induced drought stress. Australian Journal of Botany, 60: 685-692, 2012.

FAHN, A.; CUTLER, D. Xerophytes. Berlin: Gebruder Borntraeger, 1992. 176 p.

FREITAS, J. R.; CIANCIARUSO, M. V.; BATALHA, M. A. Functional diversity, soil features and community functioning: a test in a Cerrado site. Brazilian Journal of Biology, 72: 463-470, 2012.

LI-BEISSON, Y. et al. Cutin and suberin polyesters. Encyclopedia of life science (ELS), John Wiley \& Sons, Ltd: Chichester, 2016. 1-12 p.

GRATANI, L. Plant Phenotypic Plasticity in Response to Environmental Factors. Advances in Botany, 2014: 1-17, 2014.

HEIL, M. Plastic defence expression in plants. Evolutionary Ecology, 24: 555-569, 2010.

KRAUS, J.; ARDUIN, M. Manual básico de métodos em Morfologia Vegetal. Rio de Janeiro, RJ: Editora Universidade Federal Rural do Rio de Janeiro, 1997. 198 p.

MAIA, G. N. Caatinga: árvores e arbustos e suas utilidades. 2. ed. Fortaleza, CE: Printcolor Gráfica e Editora, 2012. 413 p.

MEDEIROS, C. D. et al. Leaf epicuticular wax content changes under different rainfall regimes, and its removal affects the leaf chlorophyll content and gas exchanges of Aspidosperma pyrifolium in a seasonally dry tropical forest. South African Journal of Botany, 111: 267-274, 2017.

OLIVEIRA, A. F. M.; MEIRELLES, S. T.; SALATINO, A. Epicuticular waxes from Caatinga and cerrado species and their efficiency against water loss. Anais da Academia Brasileira de Ciências, 75: 431-439, 2003

OLIVEIRA, A. F. M.; SALATINO, A. Major constituents of the foliar epicuticular waxes of species from the Caatinga and Cerrado. Zeitschrift fur Naturforschung Section C, 55: 688-692, 2000.

PAULA, M. et al. Herbivory rate on woody species of the Caatinga and NDVI as indicators of plant stress. Revista Brasileira de Geografia Física, 4: 909-921, 2011.

PEREIRA, S. et al. Changes in foliar epicuticular wax and photosynthesis metabolism in evergreen woody species under different soil water availability. Photosynthetica, 57: 192-201, 2019. 
QUESADA, M. et al. Succession and Management of Tropical Dry Forests in the Americas: Review and new perspectives. Forest Ecology and Management, 258: 1014-1024, 2009.

RAMAKRISHNA, A.; RAVISHANKAR, G. A. Influence of abiotic stress signals on secondary metabolites in plants. Plant Signaling \& Behavior, 6: 1720-1731, 2011.

RASBAND, W. S. Image J: Image Processing and Analysis in Java. Availble from the U. S. National Institutes of Health, Bethesda, Maryland, USA. 1997.

RIBEIRO, V. A. et al. Fluctuating asymmetry of and herbivory on Poincianella pyramidalis (Tul.) L.P. Queiroz (Fabaceae) in pasture and secondary tropical dry forest. Acta Botanica Brasilica, 27: 21-25, 2013.

SANT'ANNA-SANTOS B. F. et al. Anatomia e histoquímica das estruturas secretoras do caule de Spondias dulcis Forst. (Anacardiaceae). Revista Árvore, 30: 481-489, 2006.

SANTOS, J. C. et al. Caatinga: The Scientific Negligence Experienced by a Dry Tropical Forest. Tropical Conservation Science, 4: 276-286, 2011.

SANTOS, M. G. et al. Caatinga, the Brazilian dry tropical forest: can it tolerate climate changes? Theorical and Experimental Plant Physiology, 26: 83-99, 2014.

SILVA, B. L. R.; TAVARES, F. M.; ALMEIDACORTEZ, J. S. Composição florística do componente herbáceo de uma área de Caatinga Fazenda Tamanduá, Paraíba, Brasil. Revista de Geografia, 29: 54-64, 2012.

SILVA, C. H. T. P. et al. Antioxidant Capacity and Phenolic Content of Caesalpinia pyramidalis Tul. and Sapium glandulosum (L.) Morong from Northeastern Brazil. Molecules, 16: 4728-4739, jun. 2011.

VARANDA, E. M.; SANTOS, D. Y. A. C. Ceras foliares epicuticulares de espécies congêneres da Mata e do Cerrado. Acta Botanica Brasilica, 10: 51$58,1996$.

VICO, G. et al. Climatic, ecophysiological and phenological controls on plant ecohydrological strategies in seasonally dry ecosystems. Ecohydrology, 7: 658-679, 2015. 